\title{
Strategi Pengembangan Paguyuban Sripanglaras Kabupaten Kulon Progo
}

\author{
Febra Sianipar \\ Program Pascasarjana Institut Seni Indonesia Yogyakarta; \\ Jalan Suryodiningratan No. 8, Yogyakarta 55143 \\ E-mail: febrasianipar2@gmail.com
}

\begin{abstract}
ABSTRAK
Penelitian ini membahas tentang strategi pengembangan Paguyuban Sripanglaras Kabupaten Kulon Progo. Tujuan penelitian ini adalah untuk menjawab dua permasalahan yang diajukan: pertama, bagaimana kekuatan, kelemahan, peluang, dan ancaman yang dimiliki oleh Paguyuban Sripanglaras sampai dengan saat ini; dan yang kedua, bagaimana formulasi strategi pengembangan Paguyuban Sripanglaras. Untuk membedah permasalahan tersebut, peneliti menggunakan metodologi penelitian dengan metode kualitatif dengan pendekatan studi kasus. Penelitian ini menggunakan analisis SWOT sebagai alat untuk menemukan faktor internal dan faktor eksternal Paguyuban Sripanglaras. Matriks IE (internal - eksternal) Paguyuban Sripanglaras berada pada sel I yang menunjukkan tumbuh dan bina, strategi yang digunakan adalah intensif (penetrasi pasar, pengembangan pasar, dan pengembangan produk). Sedangkan kuadran analisis SWOT Paguyuban Sripanglaras berada pada posisi pertama yakni ekspansion atau mendukung strategi ofensif. Strategi pengembangan Paguyuban Sripanglaras yang dihasilkan yakni dengan menggunakan strategi campuran yang berasal dari strategi SO dan strategi WO.
\end{abstract}

Kata kunci: formulasi strategi, paguyuban sripanglaras, analisis SWOT

\section{The development strategy of the Sripanglaras Community in Kulon Progo Regency}

\begin{abstract}
This research discusses the development strategy of Paguyuban Sripanglaras Kulon Progo Regency. The purpose of this research is to answer two proposed problems: first, how are the strengths, weaknesses, opportunities, and threats of Paguyuban Sripanglaras to date; and second, how to formulate the development strategy of the Sripanglaras Association. To dissect these problems, researchers used a research methodology with qualitative methods with a case study approach. This study uses SWOT analysis as a tool to find internal and external factors of the Sripanglaras Association. IE matrix (internal-external) Paguyuban Sripanglaras is in cell I, which shows growth and development; the strategy used is intensive (market penetration, market development, and product development). Meanwhile, the SWOT analysis quadrant of the Sripanglaras Association is in the first position, namely expansion or supporting the offensive strategy. The resulting Sripanglaras association development strategy uses a mixed strategy derived from the SO strategy and the WO strategy.
\end{abstract}

Keywords: strategy formulation, the sripanglaras association, analysis SWOT 


\section{PENDAHULUAN}

Paguyuban Sripanglaras merupakan salah satu wadah seni untuk sarana belajar dan mengembangkan bakat bagi masyarakat Kabupaten Kulon Progo. Paguyuban Sripanglaras adalah paguyuban yang terbentuk berdasarkan ikatan darah dan keturunan di mana paguyuban dikelola oleh keluarga. Berdiri sejak tahun 2001 hingga saat ini, dan terletak di Dusun Pripih, Desa Hargomulyo, Kecamatan Kokap, Kabupaten Kulon Progo. Paguyuban Sripanglaras menjadi wadah untuk berbagai kegiatan kesenian seperti Tari Angguk Putri, Jathilan, Incling Putri, kelompok ketoprak anak-anak, kelompok musik anak-anak, dan kelompok membatik. Paguyuban Sripanglaras hingga saat ini mewadahi sekitar seratus enam puluh lima peserta didik dengan kesenian yang diminati masing-masing siswa.

Sripanglaras dikelola dengan bentuk pengelolaan organisasi nirlaba, artinya organisasi ini didirikan tidak bertujuan untuk mencari laba. Priharto (2020) dalam artikelnya menjelaskan bahwa organisasi nirlaba memiliki karakteristik untuk memberikan layanan kepada anggotanya atau kelompok tertentu atau kepada masyarakat umum. Organisasi nirlaba menyediakan layanan gratis atau dengan harga minimum karena tujuan mereka bukanlah untuk mendapatkan keuntungan. Sripanglaras tidak memiliki sumber pendapatan tetap, di samping itu, Sripanglaras tidak memiliki donatur atau sponsorship. Dimulai dari pembangunan gedung, pengadaan peralatan musik, pembelian kostum bagi penari, serta biaya perawatan gedung dan pembayaran ongkos transportasi pelatih tari dari luar daerah seluruhnya dipenuhi oleh pemilik paguyuban.

Secara umum, masyarakat berpendapat bahwa organisasi nirlaba sudah memiliki sumber dana untuk digunakan dalam membiayai kegiatannya. Banyak organisasi nirlaba hanya memperoleh satu jenis pendapatan saja yaitu melalui donatur. Hal ini berisiko terjadinya kelumpuhan organisasi apabila dana yang diperoleh melalui hibah kegiatan telah selesai digunakan. Oleh karena itu, sumber pendapatan lain organisasi nirlaba dapat dilakukan untuk mendukung keberlangsungan organisasi dalam menjalankan kegiatannya.

Untuk mencukupi kebutuhan biaya operasional tersebut, Sripanglaras memperoleh pemasukan melalui kegiatan program dari undangan untuk mengisi acara pertunjukan dan dari peserta didik di mana setiap anak dikenakan biaya lima ribu rupiah untuk setiap pertemuan. Akan tetapi, menurut pengelola, pemasukan melalui mengisi acara pertunjukan sering sekali tidak sesuai dengan biaya yang harus dikeluarkan, seperti untuk menutupi biaya transportasi, membayar gaji seluruh pemusik dan penari. Di samping itu, peserta didik tidak akan dikenakan biaya jika tidak menghadiri pertemuan belajar yang diadakan rutin setiap minggunya. Tak jarang pengelola Sripanglaras sering mengalami defisit akibat 
kurangnya pemasukan. Hal ini tentunya menjadi sumber masalah jika sewaktuwaktu terdapat kebutuhan yang harus dipenuhi namun pemilik paguyuban tidak lagi mampu membiayai.

Permasalahan menarik lainnya ialah kurangnya jumlah Sumber Daya Manusia (SDM). Hal tersebut dapat dilihat dari jumlah tenaga pengajar yang aktif hingga saat ini. Terdapat tiga orang tenaga pengajar berstatus tetap pada paguyuban, yakni ayah, ibu, dan anak. Ketiga tenaga pengajar tersebut secara bergantian mengajarkan seluruh kegiatan seni yang ada pada Paguyuban Sripanglaras. Latihan yang diadakan seminggu sekali dibagi menjadi dua kelas, yakni kelas anak-anak dan kelas remaja. Keterbatasan waktu dan tenaga pengajar dalam pelaksanaan proses belajar merupakan salah satu kendala yang dihadapi Sripanglaras hingga saat ini. Dengan jumlah peserta didik yang mencapai seratus enam puluh lima orang, tenaga pengajar yang terbatas, dan keterbatasan waktu dengan melaksanakan berbagai jenis kegiatan seni mengakibatkan waktu latihan menjadi tidak efektif.

Struktur organisasi yang terdapat pada Paguyuban Sripanglaras juga belum berjalan dengan maksimal. Walaupun telah memiliki susunan struktur organisasi, namun sampai dengan saat ini, paguyuban masih dikelola dengan seadanya. Tak jarang beberapa anggota harus menjalankan peran yang multifungsi dengan menempati lebih dari satu divisi. Hal ini tentunya mengakibatkan adanya peran ganda dalam pengelolaan organisasi yang tentu mengakibatkan ketidakefektifan dalam menyelesaikan pekerjaan secara profesional dan tepat waktu.

Seluruh permasalahan di atas tentu merupakan suatu masalah yang penting dan menarik untuk diteliti dalam upaya pengembangan Paguyuban Sripanglaras itu sendiri. Hal tersebut dianggap penting karena selain Sripanglaras telah menunjukkan eksistensinya dalam rentang waktu yang cukup lama, paguyuban tersebut juga memberikan dampak positif bagi pengembangan kesenian daerah yang ada di Kabupaten Kulon Progo. Dengan sejumlah permasalahan tersebut, dibutuhkan sebuah strategi pengembangan yang sesuai dengan struktur organisasi yang dimiliki oleh Paguyuban Sripanglaras. Oleh karena itu, melalui tulisan ini, peneliti akan mencoba untuk mengeksplorasi formulasi strategi pengembangan Paguyuban Sripanglaras.

\section{Analisis SWOT}

Menurut Siagian (2018: 172) analisis SWOT merupakan instrumen yang ampuh dalam melakukan analisis strategi, keampuhan tersebut terletak pada kemampuan para penentu strategi perusahaan untuk memaksimalkan peranan faktor kekuatan dan pemanfaatan peluang sehingga sekaligus berperan sebagai alat untuk meminimalisasi kelemahan yang terdapat dalam tubuh organisasi dan menekan dampak ancaman yang timbul dan harus dihadapi. Jika para penentu strategi perusahaan mampu melakukan kedua hal tersebut dengan tepat, biasanya 
upaya untuk memilih dan menentukan strategi yang efektif membuahkan hasil yang diharapkan.

Menurut Kotler (2002: 88) dan Rangkuti (2016: 19), analisis SWOT adalah identifikasi yang disusun secara sistematis untuk merumuskan strategi perusahaan. Analisis ini didasarkan pada logika yang dapat menganalisis kekuatan (strength) dan peluang (opportunities), namun secara bersamaan dapat meminimalkan kelemahan (weakness) dan ancaman (threats). Proses pengambilan keputusan harus berkaitan dengan pengembangan misi, tujuan, strategi, dan kebijakan perusahaan. Dengan demikian, perencanaan strategi harus menganalisis faktor-faktor strategi perusahaan (kekuatan, kelemahan, peluang, dan ancaman) dalam kondisi yang ada saat ini.

\section{a. Faktor-faktor berupa kekuatan}

Siagian (2018: 172-173) menjelaskan bahwa yang dimaksud dengan faktorfaktor kekuatan yang dimiliki oleh suatu perusahaan termasuk satuan-satuan bisnis di dalamnya adalah antara lain kompetensi khusus yang terdapat dalam organisasi yang berakibat pada pemilikan keunggulan komparatif oleh unit usaha di pasaran. Dikatakan demikian karena satuan bisnis memiliki sumber, keterampilan, produk andalan, dan sebagainya yang membuatnya lebih kuat dari para pesaing dalam memuaskan kebutuhan pasar yang sudah direncanakan akan dilayani oleh satuan usaha yang bersangkutan.

b. Faktor-faktor kelemahan

Siagian (2018: 173) menjelaskan jika berbicara tentang kelemahan yang terdapat di dalam tubuh suatu satuan bisnis, yang dimaksud ialah keterbatasan atau kekurangan dalam hal sumber, keterampilan, dan kemampuan yang menjadi penghalang serius bagi penampilan kinerja organisasi yang memuaskan.

c. Faktor-faktor peluang

Siagian (2018: 73) mengatakan definisi sederhana tentang peluang ialah berbagai situasi lingkungan yang menguntungkan bagi suatu satuan bisnis. Yang dimaksud dengan berbagai situasi tersebut antara lain:

1. Kecenderungan penting yang terjadi di kalangan pengguna produk.

2. Identifikasi suatu segmen pasar yang belum mendapat perhatian.

3. Perubahan dalam kondisi persaingan.

4. Perubahan dalam peraturan perundang-undangan yang membuka berbagai kesempatan baru dalam kegiatan berusaha.

5. Hubungan dengan para pembeli yang akrab.

6. Hubungan dengan pemasok yang harmonis.

d. Faktor-faktor ancaman

Siagian (2018: 173-174) menjelaskan pengertian ancaman merupakan kebalikan pengertian peluang. Dengan demikian dapat dikatakan bahwa ancaman adalah faktor-faktor lingkungan yang tidak menguntungkan suatu satuan bisnis. 
Jika tidak diatasi, ancaman akan menjadi ganjalan bagi satuan bisnis yang bersangkutan baik masa sekarang maupun di masa depan. Berbagai contohnya, antara lain, adalah:

1. Masuknya pesaing baru di pasar yang sudah dilayani oleh satuan bisnis.

2. Pertumbuhan pasar yang lamban.

3. Meningkatnya posisi tawar pembeli produk yang dihasilkan.

4. Menguatnya posisi tawar pemasok bahan mentah atau bahan baku yang diperlukan untuk diproses lebih lanjut menjadi produk tertentu.

5. Perkembangan dan perubahan teknologi yang belum dikuasai.

6. Perubahan dalam peraturan perundang-undangan restriktif.

Penelitian menunjukkan bahwa kinerja perusahaan dapat ditentukan oleh kombinasi faktor internal dan eksternal. Kedua faktor tersebut harus dipertimbangkan dalam analisis SWOT.

Berdasarkan beberapa pengertian sebelumnya, peneliti menyimpulkan bahwa analisis SWOT merupakan suatu metode yang digunakan untuk mengetahui posisi suatu organisasi, melalui identifikasi berbagai faktor secara sistematis untuk memaksimalkan faktor internal yang terdiri dari kekuatan (strength) dengan kelemahan (weaknesses), dan faktor eksternal yang terdiri dari peluang (opportunities), dengan ancaman (threats).

\section{METODE PENELITIAN}

Dalam penelitian ini, peneliti memilih tipe kualitatif dengan pendekatan studi kasus (case study) dengan single-case design. Peneliti memilih penelitian kualitatif karena sangat efektif untuk mengkaji sikap dan perilaku serta proses sosial di suatu komunitas tertentu. Penelitian kualitatif dengan studi kasus bertujuan untuk meneliti suatu permasalahan melalui studi kasus yang terdiri dari unit tunggal yaitu berarti satu orang, sekelompok penduduk, atau sekelompok masyarakat di suatu daerah dengan masalah tertentu (Creswell, 2013). Dengan demikian, tulisan ini ditujukan untuk mengeksplorasi kasus; dalam hal ini, pengorganisasian Paguyuban Sripanglaras, melalui pengumpulan data mendalam serta pengumpulan informasi yang "kaya" dalam sebuah konteks (ruang dan waktu).

Penelitian ini dilakukan dengan teknik pengumpulan data dengan beberapa cara di antaranya: 1) Observasi langsung objek penelitian yakni Paguyuban Sripanglaras; 2) Wawancara mendalam terhadap narasumber yang telah ditentukan yang dianggap mampu memberikan informasi; 3) Pengisian kuesioner oleh key person (orang yang berpengaruh pada organisasi); 4) Melakukan studi kepustakaan dengan mempelajari literatur-literatur yang berkaitan dengan topik penelitian.

Analisis data dilakukan dengan menggunakan analisis SWOT. Analisis SWOT berfungsi untuk mengidentifikasi faktor internal (kekuatan dan kelemahan) 
dan faktor eksternal (peluang dan ancaman) Paguyuban Sripanglaras. Langkah selanjutnya adalah perumusan strategi yang terdiri dari tiga tahap, yakni;

1) Tahap masukan

Pada tahapan pemasukan ada beberapa tahap yang perlu dilakukan di antaranya: a) identifikasi faktor internal dan eksternal; b) pemberian bobot;

c) pemberian peringkat, d) perkalian bobot dan peringkat.

2) Tahap pencocokan

Pada tahap pencocokan ada dua tahap yang dilakukan yaitu: a) Analisis Matriks IE (internal - eksternal); b) Matriks analisis SWOT.

3) Tahap keputusan

Tahap keputusan merupakan tahap dalam mengambil keputusan untuk menetapkan strategi yang akan digunakan pada organisasi melalui hasil analisis. Tahap keputusan diambil melalui: a) Alternatif strategi berdasarkan matriks SWOT, dan b) Tahap keputusan berdasarkan Matrik IE.

\section{PEMBAHASAN}

Berdasarkan hasil analisis peneliti pada Paguyuban Sripanglaras, maka dihasilkan faktor internal yang meliputi kekuatan (strength) dan kelemahan (weaknesses) dan faktor eksternal yang meliputi peluang (opportunities) dan ancaman (threats) sebagai berikut.

Tabel 1. Faktor Internal dan Faktor Eksternal Paguyuban Sripanglaras

\begin{tabular}{cl}
\hline ANALISIS & VARIABEL \\
\hline Faktor Internal & Kekuatan \\
& 1. Pelatih tari berkompeten. \\
2. Memiliki brand image. \\
3. Memiliki sarana dan prasarana yang lengkap. \\
4. Memiliki ragam jenis kegiatan. \\
5. Mendapat dukungan dari masyarakat. \\
6. Mendapat dukungan dari pemerintah daerah. \\
7. Memiliki eksistensi pertunjukan. \\
Kelemahan \\
1. Struktur organisasi yang ada belum berjalan dengan \\
2. Kaksimal. \\
3. Tidak memiliki sumber penghasilan tetap. \\
4. Kurangnya promosi di media sosial. \\
5. Belum memiliki visi \& misi. \\
Faktor Eksternal \\
Peluang \\
1. Menjadi paguyuban yang paling diminati. \\
2. Menjadi organisasi profit. \\
3. Banyaknya kegiatan festival seni budaya.
\end{tabular}


4. Produk kesenian unggulan menjadi salah satu identitas Kabupaten Kulon Progo.

5. Tradisi tetap terjaga.

\section{Ancaman}

1. Persaingan dengan kompetitor.

2. Perkembangan teknologi yang lebih menarik dan lebih diminati.

3. Tidak memiliki generasi penerus.

4. Kemunculan kesenian baru.

\section{Tahap Masukan}

Tahap masukan dilakukan dengan pengisian kuesioner oleh key person atau orang yang memiliki pengaruh terhadap keberlangsungan Paguyuban Sripanglaras. Pada tahapan ini peneliti menjelaskan dan mengarahkan cara pengisian kuesioner kepada ketiga key person. Peneliti berperan untuk mengawasi dan menulis jawaban yang diberikan oleh key person guna menghindari kekeliruan pemberian bobot dan peringkat terhadap faktor internal dan faktor eksternal.

\section{a. Penilaian Bobot Faktor Internal (Kekuatan \& Kelemahan)}

Melalui hasil pengisian kuesioner yang diisi oleh ketiga key person, maka diperoleh data faktor internal yang disajikan pada tabel sebagai berikut:

Tabel 2. Penilaian Bobot Faktor Internal (Kekuatan dan Kelemahan)

\begin{tabular}{ccccc}
\hline $\begin{array}{c}\text { Faktor } \\
\text { Internal }\end{array}$ & Sriwuryanti & Surajiyo & $\begin{array}{c}\text { Aprilia } \\
\text { Wedaringtyas, } \\
\text { S.Sn. }\end{array}$ & Rata-rata \\
\hline $\mathbf{A}$ & 0,087 & 0,103 & 0,082 & 0,091 \\
$\mathbf{B}$ & 0,083 & 0,112 & 0,086 & 0,094 \\
$\mathbf{C}$ & 0,083 & 0,112 & 0,094 & $\mathbf{0 , 0 9 6}$ \\
$\mathbf{D}$ & 0,083 & 0,095 & 0,086 & 0,088 \\
$\mathbf{E}$ & 0,076 & 0,099 & 0,082 & 0,086 \\
$\mathbf{F}$ & 0,083 & 0,066 & 0,064 & 0,071 \\
$\mathbf{G}$ & 0,087 & 0,091 & 0,094 & 0,091 \\
$\mathbf{H}$ & 0,080 & 0,074 & 0,075 & 0,076 \\
$\mathbf{I}$ & 0,087 & 0,062 & 0,097 & 0,082 \\
$\mathbf{J}$ & 0,083 & 0,062 & 0,071 & 0,072 \\
$\mathbf{K}$ & 0,083 & 0,062 & 0,101 & 0,082 \\
$\mathbf{L}$ & 0,083 & 0,062 & 0,067 & 0,070 \\
\hline \multicolumn{3}{c}{ Total } \\
\hline
\end{tabular}

Sumber data: diolah berdasarkan hasil penelitian, Januari 2020

Pada tabel 2 menunjukkan bahwa faktor internal Paguyuban Sripanglaras bobot tertinggi adalah memiliki sarana dan prasarana yang lengkap sebesar $\mathbf{0 , 0 9 6}$. 
b. Penilaian Bobot Faktor Eksternal (Peluang \& Ancaman)

Tabel 3. Penilaian bobot faktor eksternal (Peluang \& Ancaman)

\begin{tabular}{ccccc}
\hline $\begin{array}{c}\text { Faktor } \\
\text { Eksternal }\end{array}$ & Sriwuryanti & Surajiyo & $\begin{array}{c}\text { Aprilia } \\
\text { Wedaringtyas, } \\
\text { S.Sn. }\end{array}$ & Rata-rata \\
\hline $\mathbf{A}$ & 0,110 & 0,128 & 0,138 & 0,125 \\
$\mathbf{B}$ & 0,110 & 0,152 & 0,090 & 0,117 \\
$\mathbf{C}$ & 0,115 & 0,128 & 0,124 & 0,122 \\
$\mathbf{D}$ & 0,115 & 0,144 & 0,124 & $\mathbf{0 , 1 2 8}$ \\
$\mathbf{E}$ & 0,110 & 0,096 & 0,055 & 0,087 \\
$\mathbf{F}$ & 0,110 & 0,088 & 0,124 & 0,107 \\
$\mathbf{G}$ & 0,110 & 0,088 & 0,103 & 0,100 \\
$\mathbf{H}$ & 0,110 & 0,088 & 0,166 & 0,121 \\
$\mathbf{I}$ & 0,110 & 0,088 & 0,076 & 0,091 \\
\hline \multicolumn{3}{c}{ Total } \\
\hline
\end{tabular}

Sumber data: diolah berdasarkan hasil penelitian, Januari 2020

Pada tabel 3 menunjukkan bahwa faktor eksternal Paguyuban Sripanglaras bobot tertinggi adalah menjadi pelopor kesenian angguk sebesar putri $\mathbf{0 , 1 2 8}$.

\section{c. Pemberian Peringkat Terhadap Kekuatan}

Tabel 4. Pemberian Peringkat Terhadap Kekuatan

\begin{tabular}{|c|c|c|c|c|c|}
\hline No. & Kekuatan & Sriwuryanti & Surajiyo & $\begin{array}{c}\text { Aprilia } \\
\text { Wedaringtyas, } \\
\text { S.Sn. }\end{array}$ & Rata-rata \\
\hline 1. & $\begin{array}{l}\text { Pelatih tari } \\
\text { berkompeten. }\end{array}$ & 4 & 3 & 4 & 3,667 \\
\hline 2. & $\begin{array}{l}\text { Memiliki brand } \\
\text { image. }\end{array}$ & 3 & 3 & 4 & 3,333 \\
\hline 3. & $\begin{array}{l}\text { Memiliki sarana dan } \\
\text { prasarana yang } \\
\text { lengkap. }\end{array}$ & 3 & 3 & 3 & 3,000 \\
\hline 4. & $\begin{array}{l}\text { Memiliki ragam jenis } \\
\text { kegiatan. }\end{array}$ & 3 & 3 & 3 & 3,000 \\
\hline 5. & $\begin{array}{l}\text { Mendapat dukungan } \\
\text { dari masyarakat. }\end{array}$ & 4 & 3 & 4 & 3,667 \\
\hline 6. & $\begin{array}{l}\text { Mendapat dukungan } \\
\text { dari pemerintah daerah. }\end{array}$ & 4 & 1 & 2 & 2,333 \\
\hline 7. & $\begin{array}{l}\text { Memiliki eksistensi } \\
\text { pertunjukan. }\end{array}$ & 4 & 3 & 4 & 3,667 \\
\hline
\end{tabular}

Sumber data: diolah berdasarkan hasil penelitian, Januari 2020

Berdasarkan tabel 4, terdapat tiga indikator dengan peringkat tertinggi terhadap faktor kekuatan Sanggar Seni Sripanglaras Kabupaten Kulon Progo dengan nilai rata-rata 3,667. Ketiga indikator tersebut yakni: pelatih tari 
berkompeten, mendapat dukungan dari masyarakat, dan memiliki eksistensi pertunjukan.

\section{d. Pemberian Peringkat Terhadap Kelemahan}

Tabel 5. Pemberian Peringkat Terhadap Kelemahan

\begin{tabular}{|c|c|c|c|c|c|}
\hline No. & Kelemahan & Sriwuryanti & Surajiyo & $\begin{array}{c}\text { Aprilia } \\
\text { Wedaringtyas, } \\
\text { S.Sn. } \\
\end{array}$ & Rata-rata \\
\hline 1. & $\begin{array}{l}\text { Struktur organisasi } \\
\text { yang ada belum } \\
\text { berjalan dengan } \\
\text { maksimal. }\end{array}$ & 3 & 3 & 4 & 3,333 \\
\hline 2. & $\begin{array}{l}\text { Kurangnya jumlah } \\
\text { sumber daya manusia. }\end{array}$ & 3 & 2 & 1 & 2,000 \\
\hline 3. & $\begin{array}{l}\text { Tidak memiliki sumber } \\
\text { penghasilan tetap. }\end{array}$ & 3 & 3 & 2 & 2,667 \\
\hline 4. & $\begin{array}{l}\text { Kurangnya promosi di } \\
\text { media sosial. }\end{array}$ & 1 & 3 & 3 & 2,333 \\
\hline 5. & $\begin{array}{l}\text { Belum memiliki visi \& } \\
\text { misi. }\end{array}$ & 3 & 3 & 4 & 3,333 \\
\hline
\end{tabular}

Sumber data: diolah berdasarkan hasil penelitian, Januari 2020

Berdasarkan tabel 5, peringkat terhadap kelemahan Paguyuban Sripanglaras terendah adalah kurangnya jumlah sumber daya manusia dengan nilai rata-rata 2,000 .

\section{e. Pemberian Peringkat Terhadap Peluang}

Tabel 6. Pemberian Peringkat Terhadap Peluang

\begin{tabular}{clcccc}
\hline No. & \multicolumn{1}{c}{ Peluang } & Sriwuryanti & Surajiyo & $\begin{array}{c}\text { Aprilia } \\
\text { Wedaringtyas, } \\
\text { S.Sn. }\end{array}$ & Rata-rata \\
\hline 1. & $\begin{array}{l}\text { Menjadi paguyuban } \\
\text { yang paling diminati. }\end{array}$ & 4 & 4 & 4 & $\mathbf{4 , 0 0 0}$ \\
2. & $\begin{array}{l}\text { Dapat menjadi } \\
\text { organisasi profit }\end{array}$ & 3 & 4 & 4 & 3,667 \\
3. & $\begin{array}{l}\text { Produk kesenian } \\
\text { unggulan menjadi salah } \\
\text { satu identitas }\end{array}$ & 4 & 4 & 4 & $\mathbf{4 , 0 0 0}$ \\
$\begin{array}{l}\text { Kabupaten Kulon } \\
\text { Progo. }\end{array}$ & 4 & 4 & 4 & $\mathbf{4 , 0 0 0}$ \\
4. $\begin{array}{l}\text { Banyaknya kegiatan } \\
\text { festival seni budaya. }\end{array}$ & 3 & 2 & 2 & 2,333 \\
5radisi tetap terjaga. & & & & & \\
\hline
\end{tabular}

Sumber data: diolah berdasarkan hasil penelitian, Januari 2020

Berdasarkan tabel 6, peringkat terhadap peluang Paguyuban Sripanglaras tertinggi adalah menjadi paguyuban yang paling diminati, produk kesenian 
unggulan menjadi salah satu identitas Kabupaten Kulon Progo, dan banyaknya kegiatan festival seni budaya dengan nilai rata-rata 4,000.

\section{f. Pemberian Peringkat Terhadap Ancaman}

Tabel 7. Pemberian Peringkat Terhadap Ancaman

\begin{tabular}{clcccc}
\hline No. & \multicolumn{1}{c}{ Ancaman } & Sriwuryanti & Surajiyo & $\begin{array}{c}\text { Aprilia } \\
\text { Wedaringtyas, } \\
\text { S.Sn. }\end{array}$ & Rata-rata \\
\hline 1. & $\begin{array}{l}\text { Persaingan dengan } \\
\text { kompetitor. }\end{array}$ & 3 & 1 & 1 & 1,667 \\
2. & $\begin{array}{l}\text { Perkembangan teknologi } \\
\text { yang lebih menarik dan } \\
\text { lebih diminati. }\end{array}$ & 1 & 4 & 3 & $\mathbf{2 , 6 6 7}$ \\
3. & $\begin{array}{l}\text { Tidak memiliki generasi } \\
\text { penerus. }\end{array}$ & 1 & 3 & 2 & 2,000 \\
4. & $\begin{array}{l}\text { Kemunculan kesenian } \\
\text { baru. }\end{array}$ & 1 & 3 & 2 & 2,000 \\
\hline
\end{tabular}

Sumber data: diolah berdasarkan hasil penelitian, Januari 2020

Berdasarkan tabel 7, peringkat terhadap ancaman Paguyuban Sripanglaras tertinggi adalah perkembangan teknologi yang lebih menarik dan lebih diminati dengan nilai rata-rata $\mathbf{2 , 6 6 7 . ~}$

\section{g. Hasil Analisis Matriks IFAS (Internal Factor Analysis Summary)}

Tabel 8. Matriks IFAS (Internal Factor Analysis Summary)

\begin{tabular}{lccc}
\hline \multicolumn{1}{c}{ Faktor-faktor Strategi Internal } & Bobot & Rating & Skor* \\
\hline Kekuatan & & & \\
1. Pelatih tari berkompeten. & 0,091 & 3,667 & $\mathbf{0 , 3 3 4}$ \\
2. Memiliki brand image. & 0,094 & 3,333 & 0,313 \\
3. Memiliki sarana dan prasarana yang lengkap. & 0,096 & 3,000 & 0,288 \\
4. Memiliki ragam jenis kegiatan. & 0,088 & 3,000 & 0,264 \\
5. Mendapat dukungan dari masyarakat. & 0,086 & 3,667 & 0,315 \\
6. Mendapat dukungan dari pemerintah daerah. & 0,071 & 2,333 & 0,166 \\
7. Memiliki eksistensi pertunjukan. & 0,091 & 3,667 & $\mathbf{0 , 3 3 4}$ \\
Kelemahan & & & \\
1. Struktur organisasi yang ada belum berjalan dengan & 0,076 & 3,333 & 0,253 \\
$\quad$ maksimal. & 0,082 & 2,000 & $\mathbf{0 , 1 6 4}$ \\
2. Kurangnya jumlah sumber daya manusia. & 0,072 & 2,667 & 0,192 \\
3. Tidak memiliki penghasilan tetap. & 0,082 & 2,333 & 0,191 \\
4. Kurangnya promosi melalui media sosial. & 0,070 & 3,333 & 0,233 \\
5. Tidak memiliki visi \& misi. & & & $\mathbf{3 , 0 4 7}$ \\
\hline \multicolumn{2}{c}{ TOTAL } & &
\end{tabular}

Sumber data: diolah berdasarkan hasil penelitian, Januari 2020 
Pada tabel 8 memberikan hasil analisis matriks IFAS dengan total nilai skor sebesar 2,854. Nilai tertinggi yaitu "pelatih tari berkompeten, dan memiliki eksistensi pertunjukan" sebesar $\mathbf{0 , 3 3 4}$, sedangkan yang terendah yaitu "kurangnya jumlah sumber daya manusia" sebesar $\mathbf{0 , 1 6 4}$.

h. Hasil Analisis Matriks EFAS (External Factor Analysis Summary) Tabel 9. Matriks EFAS (External Factor Analysis Summary)

\begin{tabular}{lccc}
\hline \multicolumn{1}{c}{ Faktor-faktor Strategi Eksternal } & Bobot & Rating & Skor* \\
\hline Peluang & & & \\
1. Menjadi paguyuban yang paling diminati. & 0,125 & 4,000 & 0,500 \\
$\begin{array}{l}\text { 2. Dapat menjadi organisasi profit. } \\
\text { 3. Produk kesenian unggulan menjadi salah satu }\end{array}$ & 0,117 & 3,667 & 0,429 \\
$\quad$ identitas Kabupaten Kulon Progo. & 0,122 & 4,000 & 0,488 \\
4. Banyaknya kegiatan festival seni budaya. & 0,128 & 4,000 & $\mathbf{0 , 5 1 2}$ \\
$\begin{array}{l}\text { 5. Tradisi tetap terjaga. } \\
\text { Ancaman }\end{array}$ & 0,087 & 2,333 & 0,202 \\
$\begin{array}{l}\text { 1. Persaingan dengan kompetitor. } \\
\text { 2. Perkembangan teknologi yang lebih menarik dan }\end{array}$ & 0,107 & 1,667 & $\mathbf{0 , 1 7 8}$ \\
$\quad$ lebih diminati. & 0,100 & 2,667 & 0,267 \\
3. Tidak memiliki generasi penerus. & 0,121 & 2,000 & 0,242 \\
4. Kemunculan kesenian baru. & 0,091 & 2,000 & 0,383 \\
\hline \multicolumn{2}{c}{ TOTAL } & & $\mathbf{3 , 2 0 1}$ \\
\hline
\end{tabular}

Sumber data: diolah berdasarkan hasil penelitian, Januari 2020

Pada tabel 9 memberikan hasil analisis matriks EFAS dengan total nilai sebesar 3,201. Nilai tertinggi yaitu "banyaknya kegiatan festival seni budaya" sebesar 0,512. Sedangakan nilai terendah yaitu "persaingan dengan kompetitor" sebesar $\mathbf{0 , 1 7 8 . ~}$

\section{Tahap Pencocokan}

a. Matriks IE (Internal - Eksternal)

Matriks IE (Internal - Eksternal) Sanggar Seni Sripanglaras Kabupaten Kulon Progo

IFAS 3,047 dan EFAS 3,201

\begin{tabular}{|lc|c|c|c|}
\hline \multirow{2}{*}{ Total Skor } & \multicolumn{5}{c|}{ Total Skor IFAS } \\
EFAS & 4.0 & \multicolumn{2}{c|}{3.0} & \multicolumn{2}{c|}{2.0} \\
& 3.0 & I & II & III \\
& 2.0 & IV & V & VI \\
\cline { 3 - 5 } & 1.0 & VII & VIII & IX \\
\cline { 3 - 5 } & & & & \\
\hline
\end{tabular}


Berdasarkan matriks di atas, posisi Paguyuban Sripanglaras Kabupaten Kulon Progo menunjukkan Grow and Build (tumbuh dan bina). Strategi yang cocok adalah intensif (penetrasi pasar, pengembangan pasar, dan pengembangan produk) atau integrasi (integrasi ke belakang, integrasi ke depan, dan integrasi horizontal).

Tahap selanjutnya juga dilakukan pencocokan melalui kuadran analisis SWOT, untuk itu diperlukan bobot skor faktor internal dan bobot skor faktor eksternal. Bobot skor faktor internal diperoleh dari bobot skor Kekuatan dikurangi Kelemahan, sedangkan bobot skor faktor eksternal diperoleh dari Peluang dikurangi Ancaman.

- Bobot Skor Internal = Keunggulan - Kelemahan

$$
\begin{aligned}
& =2,014-1,033 \\
& =0,981
\end{aligned}
$$

- Bobot Skor Eksternal $=$ Peluang - Ancaman

$$
\begin{aligned}
& =2,131-1,070 \\
& =1,061
\end{aligned}
$$

Melalui pertimbangan tersebut, maka diperoleh koordinat untuk kuadran analisis SWOT yaitu (0,981:1,061). Selanjutnya, koordinat tersebut dapat digambarkan melalui kuadran analisis SWOT Paguyuban Sripanglaras Kabupaten Kulon Progo.

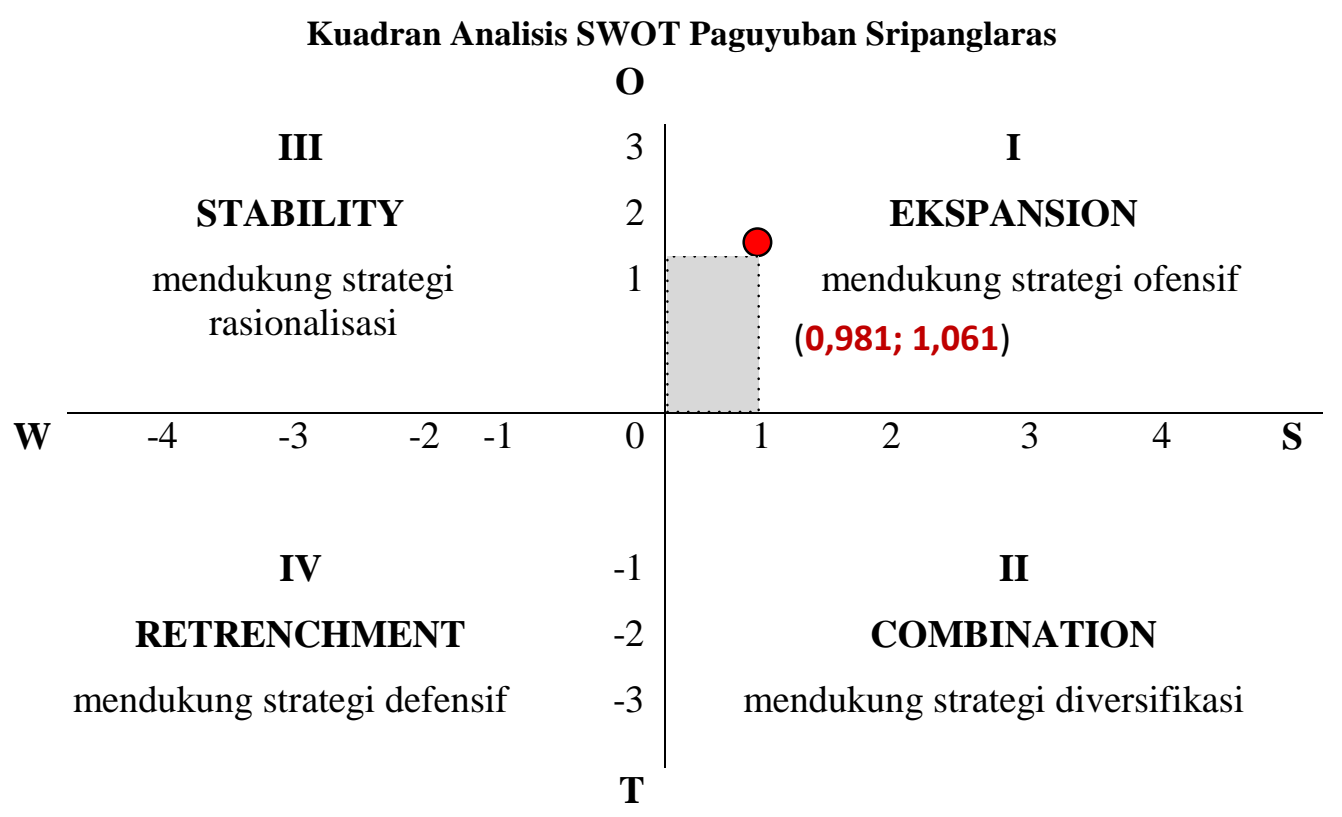


Hasil dari kuadran analisis SWOT Paguyuban Sripanglaras Kabupaten Kulon Progo berada di kuadran I Ekspansion (mendukung strategi ofensif), dengan demikian diperlukan pemilihan strategi berupa;

a. Pengembangan Pasar

Pengembangan pasar dilakukan dengan cara memperluas pasar Paguyuban Sripanglaras. Jika pasar dari Paguyuban Sripanglaras hanya berfokus pada masyarakat Kabupaten Kulon Progo, maka sebaiknya pengelola membuat pemasaran yang lebih luas dengan cara membuat kerja sama dengan pemerintah provinsi. Kerja sama dapat berupa membuat program belajar atau edukasi seni dan budaya tradisi khususnya seni tari angguk bagi bagi sekolah-sekolah dan universitas-universitas di luar daerah Kabupaten Kulon Progo.

b. Penetrasi Pasar

Penetrasi pasar Paguyuban Sripanglaras dapat dilakukan dengan mempromosikan produknya dengan cara membuat paket belajar private dengan bonus tambahan pertemuan yang lebih kepada peserta didik. Di samping itu, Sripanglaras juga dapat membuat promosi dengan cara membuat paket belajar dua jenis tarian tradisional mendapatkan bonus free satu tarian kreasi.

c. Pengembangan Produk

Pengembangan produk dapat dilakukan dengan membuat ragam jenis kegiatan seni yang baru. Di samping itu juga dapat memodifikasi gerakan tari tradisional dengan mengadopsi berbagai gerakan tarian dan iringan musik modern untuk lebih menarik minat dari peserta didik maupun calon peserta didik.

d. Integrasi ke Depan

Integrasi ke depan dapat dilakukan dengan cara membangun jaringan kerja sama dengan masyarakat desa, pemerintah daerah, dan pemerintah provinsi.

e. Integrasi ke Belakang

Integrasi ke belakang Paguyuban Sripanglaras dapat dilakukan dengan cara pembuatan kostum tari dan perlengkapan alat-alat musik secara mandiri.

f. Integrasi Horizontal

Integrasi horizontal Paguyuban Sripanglaras dapat dilakukan dengan memanfaatkan fokus kegiatan tari tradisional angguk dengan menggarap berbagai jenis kegiatan tari tradisional lainnya.

g. Diversifikasi Horizontal

Diversifikasi konsentrik dapat dilakukan dengan cara penambahan usaha garapan kesenian tari luar daerah.

\section{b. Matriks SWOT}

Berikut adalah hasil dari Matriks SWOT yang tersaji pada Tabel 10. 
Tabel 10. Alternatif Strategi Paguyuban Sripanglaras dalam Matriks SWOT

Opportunity (O)
Faktor Eksternal
1. Menjadi paguyuban yang
paling diminati.
2. Menjadi organisasi profit.
3. Banyaknya kegiatan
festival seni budaya.
4. Produk kesenian
unggulan menjadi salah
satu identitas Kabupaten
Kulon Progo.
5. Tradisi tetap terjaga.

\section{Strength (S)}

1. Pelatih tari berkompeten.

2. Memiliki brand image.

3. Memiliki sarana dan prasarana yang lengkap.

4. Memiliki ragam jenis kegiatan.

5. Mendapat dukungan dari masyarakat.

6. Mendapat dukungan dari pemerintah daerah.

7. Memiliki eksistensi pertunjukan.

1. Untuk menjadi paguyuban yang paling diminati dapat dilakukan dengan meningkatkan kualitas produk dan jasa sebagai daya tarik minat belajar masyarakat.

(O1, O2, 03, 04, S1, S2, S3, S4, S5, S6, S7)

2. Bekerja sama dengan masyarakat dan pemerintah daerah untuk membuat sarana edukasi tentang kesenian asli daerah, terutama dengan dinas pariwisata dan budaya agar mengarahkan wisatawan lokal dan wisatawan mancanegara untuk berkunjung ke paguyuban. (O2, O3, O4, O5, S1, S4, S5, S6)

3. Melakukan kerja sama dengan cara melibatkan masyarakat dan pemerintah daerah untuk membuat kegiatan pertunjukan rutin setiap tahun.

(O3, O5, S2, S5, S6)

4. Memperkenalkan dan mengajarkan berbagai kesenian tradisonal untuk menumbuhkan rasa cinta terhadap tradisi melalui instansi-instansi

\section{Weakness (W)}

1. Struktur organisasi yang ada belum berjalan dengan maksimal.

2. Kurangnya jumlah sumber daya manusia.

3. Tidak memiliki sumber penghasilan tetap.

4. Kurangnya promosi di media sosial.

5. Belum memiliki visi \& misi.

\section{Strategi WO}

1. Memperbaiki struktur organisasi dengan menempatkan orang tepat agar memiliki kualitas sehingga memiliki pengelolaan yang baik untuk dapat membuat sumber pemasukan tetap. (01, 02, W1, W2, W3, W4)

2. Meningkatkan promosi terkait kegiatan seni tradisi yang ada pada paguyuban dengan menggunakan media cetak dan memanfaatkan media sosial seperti Youtube, Facebook, Instagram, dan media sosial lainnya agar lebih banyak yang mengetahui.

(01, 02, 03, 04, 05, W3, W4)

3. Membuat perencanaan kegiatan tujuan jangka pendek, jangka menengah, dan jangka panjang. (01, 02, 05, W5) 
pemerintah, sekolah, dan

universitas.

(O3, O4, 05, S1, S1, S3,

S4, S5, S6, S7)

\section{Threat (T)}

1.Persaingan dengan

kompetitor lain.

2.Perkembangan teknologi yang lebih menarik dan lebih diminati.

3. Tidak memiliki generasi penerus.

4. Kemunculan kesenian baru.
1. Memanfaatkan pelatih tari yang berkompeten dan meningkatkan kualitas sarana dan prasarana untuk mempertahankan keunggulan paguyuban agar lebih unggul dari kompetitor lain.

(T1, T2, T4, S1, S2, S3, S4, S7)

2. Bekerja sama dengan masyarakat dan pemerintah daerah untuk membuat aplikasi belajar seni tradisi. (T2, T4, S5, S6, S7)

3. Mengajak dan mengajarkan peserta didik cara mengelola paguyuban yang baik dan benar.

(T3, S1)

4. Mengembangkan kegiatan seni tradisional dengan melakukan kolaborasi terhadap seni lainnya.

(T1, T4, S1, S4)

\section{Tahap Keputusan}

\section{a. Tahap Keputusan Berdasarkan Matriks SWOT}

Berdasarkan hasil Matriks SWOT sebelumnya, maka dapat disimpulkan strategi yang dapat digunakan oleh pengelola Paguyuban Sripanglaras adalah strategi campuran yang berasal dari strategi SO dan strategi WO yaitu:

1. Untuk menjadi paguyuban yang paling diminati dapat dilakukan dengan meningkatkan kualitas produk dan jasa sebagai daya tarik minat belajar masyarakat.

2. Bekerja sama dengan masyarakat dan pemerintah daerah untuk membuat sarana edukasi tentang kesenian asli Kabupaten Kulon Progo, terutama dengan Dinas Pariwisata dan Budaya agar mengarahkan wisatawan lokal dan wisatawan mancanegara untuk berkunjung ke Paguyuban Sripanglaras.

3. Memperkenalkan dan mengajarkan berbagai kesenian tradisional untuk menumbuhkan rasa cinta terhadap tradisi melalui instansi-instansi pemerintah, sekolah, dan universitas. 
4. Memperbaiki struktur organisasi dengan menempatkan orang tepat agar memiliki kualitas sehingga memiliki pengelolaan yang baik untuk dapat membuat sumber pemasukan tetap.

5. Meningkatkan promosi terkait kegiatan seni tradisi yang ada pada paguyuban dengan menggunakan media cetak dan memanfaatkan media sosial seperti YouTube, Facebook, Instagram, dan media sosial lainnya agar lebih banyak yang mengetahui.

6. Membuat perencanaan kegiatan tujuan jangka pendek, jangka menengah, dan jangka panjang.

\section{b. Tahap Keputusan Berdasarkan Matriks IE}

Dilihat dari hasil analisis matriks IE, posisi Paguyuban Sripanglaras menunjukkan Growth and Build (tumbuh dan bina) berada pada pada sel I adalah strategi Intensif atau Integrasi. Penetrasi pasar Paguyuban Sripanglaras dapat dilakukan dengan: (1) Mempromosikan produknya dengan cara membuat paket belajar private dengan bonus tambahan pertemuan yang lebih kepada peserta didik; (2) Membuat promosi dengan cara membuat paket belajar dua jenis tarian tradisional mendapatkan bonus free satu tarian kreasi; (3) Mempromosikan tiap pendaftar mendapatkan free kostum tari.

Pengembangan pasar dilakukan dengan cara memperluas pasar Paguyuban Sripanglaras. Jika pasar dari Paguyuban Sripanglaras hanya berfokus pada masyarakat Kabupaten Kulon Progo, maka sebaiknya pengelola membuat pemasaran yang lebih luas dengan cara membuat kerja sama dengan pemerintah provinsi. Kerja sama dapat berupa membuat program belajar atau edukasi seni dan budaya tradisi khususnya seni tari angguk bagi sekolah-sekolah dan universitasuniversitas di luar daerah Kabupaten Kulon Progo. Pengembangan produk dapat dilakukan dengan membuat ragam jenis kegiatan seni yang baru. Di samping itu, juga dapat memodifikasi gerakan tari tradisional dengan mengadopsi berbagai gerakan tarian dan iringan musik modern untuk lebih menarik minat dari peserta didik maupun calon peserta didik.

\section{c. Strategi Pengembangan Paguyuban Sripanglaras berdasarkan Matriks IE}

Dilihat dari hasil analisis Matriks IE menunjukkan bahwa posisi usaha Paguyuban Sripanglaras berada pada sel I yang berarti Grow and Build (tumbuh dan bina). Strategi yang cocok untuk strategi ini adalah strategi intensif (penetrasi pasar, pengembangan pasar, dan pengembangan produk). Strategi penetrasi pasar dimaksudkan untuk meningkatkan pangsa pasar melalui usaha-usaha pemasaran. Cara melaksanakan penetrasi pasar dengan menggencarkan unsur bauran pemasaran promosi dan harga, yaitu melalui menaikkan jumlah tenaga penjualan, 
meningkatkan anggaran iklan, menawarkan secara gencar berbagai item promosi penjualan, atau bahkan meningkatkan aktivitas publisitas. Dalam hal ini peneliti membuat strategi penetrasi pasar dengan menawarkan secara gencar produk kegiatan seni yang ada pada Paguyuban Sripanglaras dengan promosi penjualan yang memberikan bonus untuk setiap penggunaan jasa.

Pengembangan pasar dapat dilakukan dengan memperluas area geografi baru, menambah segmen baru, mengubah dari bukan pemakai menjadi pemakai, menarik pelanggan pesaing. Dalam membuat pengembangan pasar, peneliti menawarkan untuk membuat strategi dengan mencoba membuat area geografis baru, segmen baru di luar daerah melalui kerja sama antar-paguyuban dengan pemerintah provinsi untuk membuat program belajar atau edukasi seni budaya tradisi khususnya kesenian tari angguk bagi sekolah-sekolah dan universitasuniversitas di luar daerah.

Pengembangan produk dapat dilakukan dengan memperbaiki dan mengembangkan produk yang ada pada saat ini. Dalam hal ini peneliti menawarkan strategi mengembangkan produk yang ada saat ini dengan memodifikasi produk yakni tari yang dikolaborasikan dengan musik modern atau mengadopsi gerakan tarian yang lebih kekinian untuk menarik minat pesersta didik maupun calon peserta didik.

\section{KESIMPULAN}

Kesimpulan penelitian berdasarkan Matriks IE (Internal - Eksternal) menunjukkan pada posisi sel I yang berarti Grow and Build (tumbuh dan bina). Strategi yang dapat digunakan adalah intensif: (1) Penetrasi Pasar; (a) mempromosikan produknya dengan cara membuat paket belajar private dengan bonus tambahan pertemuan yang lebih kepada peserta didik, (b) membuat promosi dengan cara membuat paket belajar dua jenis tarian tradisional mendapatkan bonus free satu tarian kreasi, (c) mempromosikan tiap pendaftar mendapatkan free kostum tari. (2) Pengembangan Pasar, yang dilakukan dengan cara memperluas pasar Paguyuban Sripanglaras. Jika pasar dari Paguyuban Sripanglaras hanya berfokus pada masyarakat Kabupaten Kulon Progo, maka sebaiknya pengelola membuat pemasaran yang lebih luas dengan cara membuat kerja sama dengan pemerintah provinsi. Kerja sama dapat berupa membuat program belajar atau edukasi seni dan budaya tradisi khususnya seni tari angguk bagi sekolah-sekolah dan universitasuniversitas di luar daerah Kabupaten Kulon Progo. (3) Pengembangan Produk; Pengembangan produk dapat dilakukan dengan membuat ragam jenis kegiatan seni yang baru. Di samping itu, juga dapat memodifikasi gerakan tari tradisional dengan mengadopsi berbagai gerakan tarian dan iringan musik modern untuk lebih menarik minat dari peserta didik maupun calon peserta didik. 
Matriks SWOT menunjukkan pengembangan Paguyuban Sripanglaras dapat dilakukan dengan menggunakan strategi campuran SO dan strategi WO yaitu; (a) Untuk menjadi paguyuban yang paling diminati dapat dilakukan dengan meningkatkan kualitas produk dan jasa sebagai daya tarik minat belajar masyarakat. (b) Bekerja sama dengan masyarakat dan pemerintah daerah untuk membuat sarana edukasi tentang kesenian asli Kabupaten Kulon Progo, terutama dengan dinas pariwisata dan budaya agar mengarahkan wisatawan lokal dan wisatawan mancanegara untuk berkunjung ke paguyuban. (c) Memperkenalkan dan mengajarkan berbagai kesenian tradisonal untuk menumbuhkan rasa cinta terhadap tradisi melalui instansi-instansi pemerintah, sekolah, dan universitas. (d) Memperbaiki struktur organisasi dengan menempatkan orang tepat agar memiliki kualitas sehingga memiliki pengelolaan yang baik untuk dapat membuat sumber pemasukan tetap. (e) Meningkatkan promosi terkait kegiatan seni tradisi yang ada pada paguyuban dengan menggunakan media cetak dan memanfaatkan media sosial seperti YouTube, Facebook, Instagram, dan media sosial lainnya agar lebih banyak yang mengetahui. (f) Membuat perencanaan kegiatan tujuan jangka pendek, jangka menengah, dan jangka panjang.

\section{KEPUSTAKAAN}

Ardiyasa, I. P. (2015). Strategi Pengelolaan Sanggar Seni Anacaraka dalam Mewadahi Bakat Anak-anak di Pegunungan Kintamani Bali. Jurnal Tata Kelola Seni, 1(2), 31-45. https://doi.org/https://doi.org/10.24821/jtks.v1i2.1639

Creswell, J. W. (2013). Qualitative Inquiry and Research Design (L. Habib (ed.); Third). California: SAGE Publications Ltd.

David, F. R. (2006). Manajemen Strategis (10th ed.). Jakarta: Salemba Empat.

David, Fred R.; \& Forest, R. D. (2016). Manajemen Strategik. Jakarta Selatan: Salemba Empat.

Dinas Kebudayaan Pariwisata Pemuda dan Olah Raga Kabupaten Kulon Progo. (2015). Kesenian Unggulan Kulon Progo. Daerah Istimewa Yogyakarta.

Dirgantoro, C. (2001). Manajemen Stratejik: Konsep, Kasus, dan Implementasi. Jakarta: PT Grasindo.

Fahmi, I. (2014). Manajemen Teori, Kasus, dan Solusi. Bandung: Alfabeta.

Fatimah, F. N. D. (2016). Teknik Analisis SWOT. Yogyakarta: Quadrant.

Handoko, T. H. (2015). Manajemen. Yogyakarta: BPFE Yogyakarta.

Haryanto, D.; \& Nugrohadi, G. E. (2011). Pengantar Sosiologi Dasar. Jakarta: Prestasi Pustaka.

Indrawijaya, A. I. (2014). Teori Perilaku, dan Budaya Organisasi. Bandung: PT Refika Aditama.

Kotler, P. (2002). Manajemen Pemasaran. Jakarta: PT Prenhallindo.

Mappasiara. (2018). Manajemen Strategik Dan Manajemen Operasional Serta Implementasinya Pada Lembaga Pendidikan. Idaarah: Jurnal Manajemen 
Pendidikan, 2(1), 74-85.

https://doi.org/https://doi.org/10.24252/idaarah.v2i1.5116

Nawai, Fory A. (2016). Strategi Pengelolaan Pembelajaran. Gorontalo: Ideas Publishing.

Pearce, Jhon A.; \& Richard, B. R. (2016). Manajemen Strategis; Formulasi, Implementasi, dan Pengendalian. Jakarta Selatan: Salemba Empat.

Pujiwiyana. (2010). Pembinaan Paguyuban Seni Tradisional. Yogyakarta: Elmatera.

Rahadi, Dedi Rianto; Cakranegara, Pandu; Claudia, G. (2018). Case Study of Recruitment and Selection of Employees in the Family Businesses of Tasikmalaya. IJFBP: International Journal of Family Business Practices, 1(2), 139-150. https://doi.org/http://dx.doi.org/10.33021/ijfbp.v1i2.644

Rangkuti, F. (2016). Analisis SWOT: Teknis Membedah Kasus Bisnis Cara Perhitungan Bobot, Rating dan OCAL. Jakarta: PT Gramedia Pustaka Utama.

Rifa'i, H. M. \& M. F. (2013). Manajemen Organisasi. Bandung: Cita Pustaka Media Perintis.

Rivai, Abdul; \& Darsono, P. (2015). Manajemen Strategis. Jakarta: Mitra Wacana Media.

Siagian, S. P. (2018). Manajemen Stratejik. Jakarta: PT Bumi Aksara.

Sukarna. (2011). Dasar-Dasar Manajemen. Bandung: CV Mandar Maju.

Torang, S. (2013). Organisasi dan Manajemen (Perilaku, Struktur, Budaya dan Perubahan Organisasi). Bandung: Alfabeta.

Umam, K. (2015). Manajemen Organisasi. Bandung: CV Pustaka Setia.

Vellas, F. \& L. B. (2008). Pemasaran Pariwisata Internasional. Jakarta: Yayasan Obor Indonesia.

Wheelen, T. L. . \& J. D. H. (2012). Strategic Management and Business Policy. USA: Prentice Hall.

\section{Webtografi}

Priharto, S. (2020). Organisasi Nirlaba: Pengertian, Ciri-cirinya, dan Contohnya di Indonesia. Retrieved from accurate website: https://accurate.id/bisnisukm/pengertian-organisasi-nirlaba/

Rahardjo, M. (2010). Triangulasi Dalam Penelitian Kualitatif. Retrieved November 17, 2020, from https://www.uin-malang.ac.id/r/101001/triangulasi-dalampenelitian-kualitatif.html

Republika.co.id. (2014). Jumlah Organisasi Seni Budaya di Indonesia Terus Menurun. Retrieved January 30, 2021, from https://www.republika.co.id/berita/n0x8ln/jumlah-organisasi-seni-budayadi-indonesia-terus-menurun 